\section{Pseudomembranous colitis in a patient with lamotrigine-induced drug rash with eosinophilia and systemic symptoms syndrome}

\author{
Manuel Soria Orozco, ${ }^{1}$ \\ Eduardo Martín Nares, ${ }^{1}$ \\ Alvaro López Iñiguez, ${ }^{1}$ \\ Sandra Gónzalez Saldaña, ${ }^{1}$ \\ Lorena Valerdi Contreras, ${ }^{1}$ \\ Jair Abdiel Toro Guerrero ${ }^{2}$
}

1 Department of Internal Medicine and

2Department of Pathology, Civil Hospital

Fray Antonio Alcalde, Guadalajara,

Jalisco, Mexico

\section{Abstract}

Drug reaction with eosinophilia and systemic symptoms (DRESS) syndrome is a hypersensitivity reaction with rash, fever and multiorgan dysfunction potentially lethal in up to $10 \%$ of cases. It often affects liver function, but it can also affect kidney, lungs, and heart. Severe gastrointestinal involvement is rare. We present a case of a 31-year-old hispanic woman with pseudomembranous colitis associated with lamotrigine-induced DRESS syndrome. To the best of our knowledge, this is the fourth reported case of severe involvement of the gastrointestinal tract and the first to report pseudomembranous colitis in the setting of DRESS syndrome.

\section{Introduction}

Drug reaction with eosinophilia and systemic symptoms (DRESS) syndrome, also known as DIHS (drug induced hypersensitivity syndrome), is a potentially lethal and many times under diagnosed idiosyncratic reaction associated with several drugs, specially antiepileptic medication. ${ }^{1}$

Patients with DRESS syndrome typically present with skin rash (a generalized maculopapular rash with follicular accentuation and sometimes facial edema with periorbital predominance), eosinophilia, fever and systemic manifestations such as a liver, renal, cardiac and pulmonary involvement. However, gastrointestinal involvement has been rarely described in literature. ${ }^{2}$

Although DRESS syndrome pathophysiology is still unknown, eosinophilic infiltrates are probably the mechanism of multi organic damage. ${ }^{3,4}$ Other possible mechanisms are abnormalities in drug detoxification enzymes with subsequent accumulation of metabolites and sequential activation of herpes virus such as cytomegalovirus, Epstein-Barr, and human
Correspondence: Manuel Soria Orozco, Department of Internal Medicine, Civil Hospital Fray Antonio Alcalde, Av. Hospital 278, Sector Hidalgo, C.P. 44280 Guadalajara Jalisco, Mexico. Tel.: +52.011.52.333.614.5501.

E-mail:manuelspitz@hotmail.com

Key words: DRESS syndrome; Multiorgan involvement; Pseudomembranous colitis; Lamotrigine; Anticonvulsant hypersensitivity syndrome.

Contributions: MSO, EMN, conception and design, drafting of the article, critical revision of intellectual content and final approval of the version to be published; ALI and SGS, drafting of the article, critical revision of intellectual content; LVC and JATG, critical revision of intellectual content and final approval of the version to be published.

Conflict of interest: the authors declare no potential conflict of interest.

Received for publication: 2 March 2016. Revision received: 6 May 2016.

Accepted for publication: 11 May 2016.

This work is licensed under a Creative Commons Attribution NonCommercial 4.0 License (CC BYNC 4.0).

(C) Copyright M.S. Orozco et al., 2016 Licensee PAGEPress, Italy

Gastroenterology Insights 2016; 7:6491 doi:10.4081/gi.2016.6491

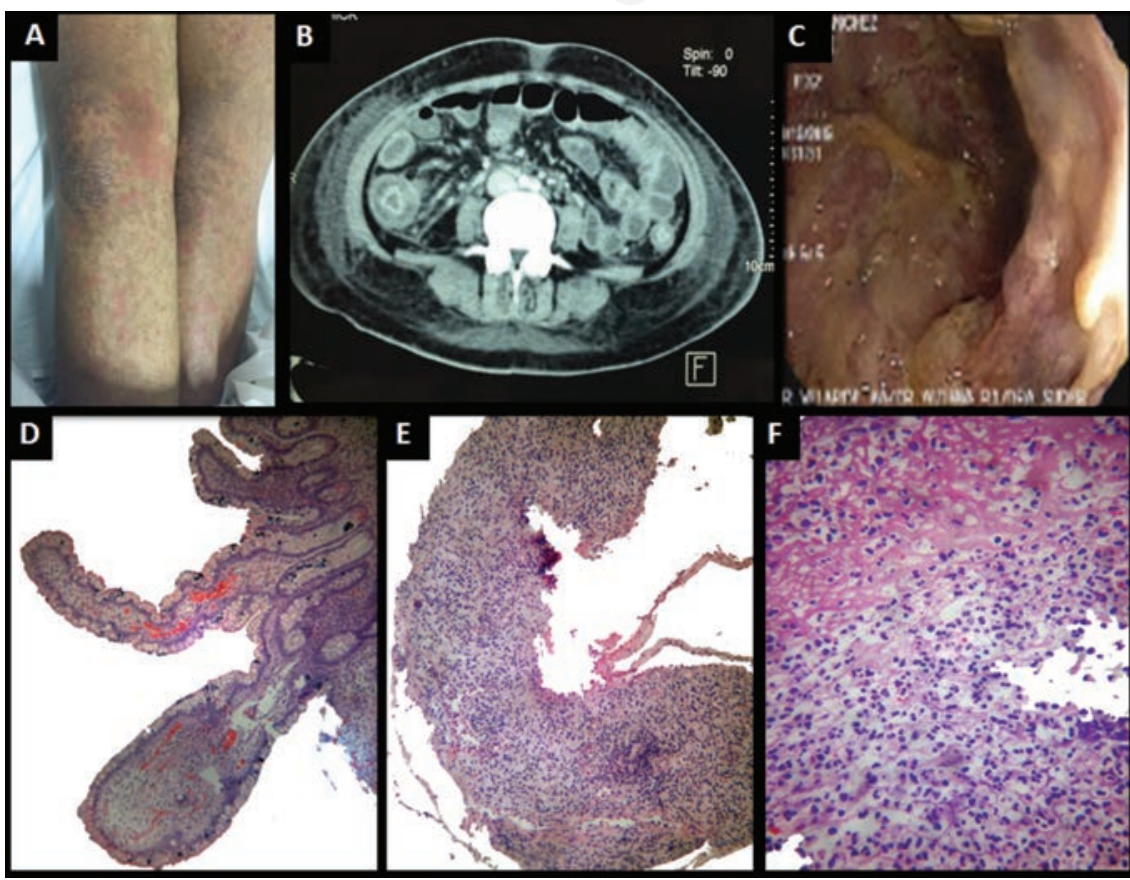

Figure 1. A) Patient showing a maculopapular rash on limbs with follicular accentuation; B) abdominal contrastenhanced computed tomography scan showing generalized colonic wall edema; C) endoscopy revealing presence of pseudomembranes in sigmoid and rectum; D) photomicrographs HE-Section (10x) showing fragment of ileal mucosa with focal erosion, edema in the lamina propria and subtle increased number of inflammatory cells with predominance of mononuclear cells within terminal ileum $(E),(4 \times)$ fragment of ulcerated colonic mucosa with extensive loss of crypts and presence of mixed inflammatory infiltrate. F) At a higher magnification $(10 \times)$, fibrinoidnecrotic material, cellular debris and dense inflammatory infiltrate of lymphocytes, macrophages and numerous polymorphonuclear leukocytes essentially neutrophils are seen. 
herpes virus 6 and $7 .^{5}$ Likewise it has been found predisposition mediated by leukocyte antigen alleles such as HLA-B*58:01 for allopurinol $^{6}$ and HLA-A*31:01 for carbamazepine. ${ }^{7}$ On the other hand, vitamin D deficiency has been implicated as a possible contribution to the pathogenesis DRESS syndrome for its protective effects against inflammatory and autoimmune conditions. ${ }^{5}$

Pseudomembranous colitis is a manifestation of severe colonic disease. It can be associated with different etiologies. The list of associated etiologies is vast, although Clostridium difficile infection (CDI) remains the most common cause..$^{8,9}$

The following case report demonstrates the wide spectrum of multiorgan involvement associated with DRESS syndrome, including gastrointestinal involvement in the form of pseudomembranous colitis.

\section{Case Report}

A 31-year-old Hispanic woman presented to our clinic with a one-month history of fever and maculopapular rash, and diarrhea of oneweek duration; she had a diagnosis of epilepsy and had been prescribed lamotrigine two weeks before initiation of these symptoms. On admission, her vital signs were as follows: temperature of $39.5^{\circ} \mathrm{C}$, heart rate of $120 / \mathrm{min}$, respiratory rate of $18 / \mathrm{min}$, systemic blood pressure of 110/60, and oxygen saturation of $96 \%$. At physical examination she had a left retroauricular adenopathy, a maculopapular confluent rash over the trunk and limbs with follicular accentuation (Figure 1A), diminished breath sounds at both lung bases and bilateral lower limb edema. The rest of examination was unremarkable.

Initial laboratory findings revealed hemoglobin of $8.35 \mathrm{~g} / \mathrm{dL}(\mathrm{N}=12.20-18.10)$, platelets of $84,000 / \mathrm{mm}^{3} \quad(\mathrm{~N}=142,000-450,000)$, white blood cells of $10,500 / \mathrm{mm}^{3}(\mathrm{~N}=4600-10200)$, with hypereosinophilia $1800 / \mathrm{mm}^{3} \quad(\mathrm{~N}=0$ $500 / \mathrm{mm}^{3}$ ), aspartate aminotransferase (AST) of $144.70 \mathrm{U} / \mathrm{L}(\mathrm{N}=10-50 \mathrm{u} / \mathrm{L})$, and alanine aminotransferase (ALT) of $120.31 \mathrm{U} / \mathrm{L}(\mathrm{N}=0$ 41 ), creatinine of $2.47 \mathrm{mg} / \mathrm{dL}$ (baseline of 0.78 $\mathrm{mg} / \mathrm{dL})$, and urea of $76.4(\mathrm{~N}=15-39)$ were obtained. Stool examination was positive for 50 polymorphonuclear cells per field and no evidence of parasites or ova. Serum electrolytes and urinalysis were normal. During hospitalization she developed bloody diarrhea and further investigations were obtained. Other laboratory findings are shown on Table 1. The electrocardiogram and echocardiogram were unremarkable. Bone marrow aspirate showed moderate eosinophilia and hemophagocytosis. Skin biopsy reported interface dermatitis. Chest computed tomography (CT) scan revealed bilateral pleural effusions and passive atelectasis. Abdominal contrastenhanced CT scan showed generalized intestinal and colonic wall edema suggestive of colitis (Figure 1B); colonoscopy was performed revealing pancolitis, ulcerative ileitis and presence of pseudomembranes in sigmoid and rectum (Figure 1C). Histopathological analysis of colonic biopsies reported ulcerated mucosa with fibrinoid material and inflammatory infiltrates with polymorphonuclear leukocytes compatible with sub-acute colitis, without characteristics consistent with inflammatory bowel disease, and no evidence of granulomas, pathogenic organisms or viral inclusions (Figure 1D-F). Because of the high prevalence in our hospital for CDI, and the fact that she had been treated with several antibiotics for presumed brucellosis previous to admission, polymerase chain reaction (PCR) for Clostridium difficile in stool was performed and was reported negative. After exclusion of infectious, autoimmune/inflammatory and neoplastic diseases, she was diagnosed with pseudomembranous colitis associated with lamotrigine-induced DRESS syndrome and treatment was started

Table 1. Laboratory findings.

\begin{tabular}{|c|c|}
\hline Test & Result (reference) \\
\hline Hemoglobin & $8.35 \mathrm{~g} / \mathrm{dL}(\mathrm{N}=12.20-18.10)$ \\
\hline White cells & $10,500 / \mu \mathrm{L}(\mathrm{N}=4600-10,200)$ \\
\hline Lymphocytes & $1800 / \mu \mathrm{L}$ \\
\hline Neutrophils & $5200 / \mu \mathrm{L}$ \\
\hline Eosinophils & $1890 / \mu \mathrm{L}$ \\
\hline Platelets & $285,000 / \mu \mathrm{L}(\mathrm{N}=142,000-450,000)$ \\
\hline Glucose & $90 \mathrm{mg} / \mathrm{dL}(\mathrm{N}=60-125)$ \\
\hline Urea & $76.4(\mathrm{~N}=15-39)$ \\
\hline Creatinine & $2.47(\mathrm{~N}=0.4-1.1)$ \\
\hline Aspartate aminotransferase & 144 IU/L (N=10-42) \\
\hline Alanine aminotransferase & $120.31 \mathrm{IU} / \mathrm{L}(\mathrm{N}=10-40)$ \\
\hline Alkaline phosphatase & $618 \mathrm{IU} / \mathrm{L}(\mathrm{N}=32-92)$ \\
\hline Lactic dehydrogenase & $124 \mathrm{IU} / \mathrm{L}(\mathrm{N}=91-180)$ \\
\hline Total protein & $6.76 \mathrm{~g} / \mathrm{dL}(\mathrm{N}=6.3-8.2)$ \\
\hline Albumin & $3.81 \mathrm{~g} / \mathrm{dL}(\mathrm{N}=3.5-5)$ \\
\hline Uric acid & $4.8 \mathrm{mg} / \mathrm{dL}(\mathrm{N}=2-6.5)$ \\
\hline Cholesterol & $120 \mathrm{mg} / \mathrm{dL}(\mathrm{N}=150-200)$ \\
\hline Triglycerides & $129 \mathrm{mg} / \mathrm{dL}(\mathrm{N}=35-160)$ \\
\hline Serum iron & $45 \mathrm{ng} / \mathrm{dL}(\mathrm{N}=40-160)$ \\
\hline Ferritin & $452 \mathrm{ng} / \mathrm{dL}(\mathrm{N}=4.5-260)$ \\
\hline C-reactive protein & 8.14 mg/dL $(\mathrm{N}<10)$ \\
\hline Erythrocyte sedimentation rate & 22 mm/hr $(\mathrm{N}<10)$ \\
\hline Procalcitonin & $0.44 \mathrm{ng} / \mathrm{dL}(\mathrm{N}<0.50)$ \\
\hline HIV serology & Negative \\
\hline Hepatitis B virus serology & Negative \\
\hline Hepatitis C virus serology & Negative \\
\hline Cytomegalovirus serology & Negative \\
\hline Epstein Barr virus serology & Negative \\
\hline Rose Bengal test & Negative \\
\hline 2-mercaptoethanol & Negative \\
\hline Blood cultures & Negative \\
\hline Urine culture & Negative \\
\hline Polymerase chain reaction for $C$.difficile & Negative \\
\hline C3 & $103 \mathrm{mg} / \mathrm{dL}(\mathrm{N}=90-180)$ \\
\hline $\mathrm{C} 4$ & $11.9 \mathrm{mg} / \mathrm{dL}(\mathrm{N}=10-40)$ \\
\hline Direct Coombs test & Negative \\
\hline Rheumatoid factor & $10.4 \mathrm{UI} / \mathrm{mL}(\mathrm{N}=0-15.0)$ \\
\hline Antinuclear antibodies & Negative \\
\hline
\end{tabular}


Table 2. Summary of published reports of cases that showed sever involvement of digestive tract in association with drug reaction with eosinophilia and systemic symptoms.

\begin{tabular}{|c|c|c|c|c|c|c|c|c|c|}
\hline Authors & Year & Patient & $\begin{array}{c}\text { Regi } \\
\text { SCAR score }\end{array}$ & $\begin{array}{l}\text { Drug } \\
\text { implicated }\end{array}$ & $\begin{array}{l}\text { Systemic } \\
\text { symptoms }\end{array}$ & GI symptoms & Endoscopy & Treatment & Outcome \\
\hline $\begin{array}{l}\text { Do-Pham } \\
\text { et al. }{ }^{12}\end{array}$ & 2011 & $70 \mathrm{~F}$ & 6 & Leflunomide & $\begin{array}{l}\text { Hematologic, } \\
\text { renal, } \\
\text { liver affection }\end{array}$ & Diarrhea & $\begin{array}{c}\text { Circumferential } \\
\text { erosive esophagitis } \\
\text { and ulcerative colitis }\end{array}$ & $\begin{array}{cc}\text { Diffuse } & \text { Ganciclovir and } \\
\text { inflammatory } & \text { antibiotic } \\
\text { lymphocytic } & \text { therapy } \\
\text { infiltrate without } & \\
\text { granuloma, } \\
\text { eosinophils or } \\
\text { viral inclusions }\end{array}$ & $\begin{array}{c}\text { Patient died } \\
\text { from a } \\
\text { massive } \\
\text { digestive } \\
\text { hemorrhage } \\
5 \text { weeks after }\end{array}$ \\
\hline $\begin{array}{l}\text { Do-Pham } \\
\text { et al. }{ }^{12}\end{array}$ & 2011 & $28 \mathrm{~F}$ & 7 & Lamotrigine & $\begin{array}{l}\text { Hematologic, } \\
\text { renal, } \\
\text { pulmonary } \\
\text { affection }\end{array}$ & $\begin{array}{l}\text { Bloody } \\
\text { diarrhea }\end{array}$ & $\begin{array}{l}\text { Diffuse } \\
\text { ulcerating } \\
\text { colitis }\end{array}$ & $\begin{array}{cc}\begin{array}{c}\text { Inflammatory } \\
\text { infiltrate }\end{array} & \text { Systemic } \\
\text { corticosteroids, } \\
\text { mostly } & \text { which were } \\
\text { including } & \text { replaced by local } \\
\text { lymphocytes } & \text { corticosteroids } \\
\text { without either } & \\
\text { eosinophils } & \\
\text { or cytomegalovirus } \\
\text { inclusions within } \\
\text { the colon }\end{array}$ & $\begin{array}{l}\text { Symptoms } \\
\text { resolved }\end{array}$ \\
\hline $\begin{array}{l}\text { Swanson } \\
\text { et al. }\end{array}$ & 2014 & $21 \mathrm{~F}$ & 6 & $\begin{array}{l}\text { Phenytoin, } \\
\text { lamotrigine }\end{array}$ & $\begin{array}{l}\text { Hematologic, } \\
\text { liver affection }\end{array}$ & $\begin{array}{l}\text { Nausea, } \\
\text { vomiting, } \\
\text { diarrhea }\end{array}$ & $\begin{array}{l}\text { Duodenopathy } \\
\text { with ulceration } \\
\text { and submucosal } \\
\text { hemorrhage. } \\
\text { Erythematous, } \\
\text { granular, } \\
\text { and friable mucosa } \\
\text { with multiple } \\
\text { rectal and } \\
\text { sigmoid ulcers }\end{array}$ & $\begin{array}{c}\text { Severe chronic } \\
\text { Oral steroid } \\
\text { colitis and mucosal } \\
\text { taper } \\
\text { damage with } \\
\text { prominent crypt } \\
\text { destruction and loss. } \\
\text { Mixed } \\
\text { inflammation } \\
\text { composed } \\
\text { of lymphocytes, } \\
\text { plasma cells, } \\
\text { histiocytes, } \\
\text { and neutrophils. }\end{array}$ & $\begin{array}{l}\text { Patient died } \\
\text { from HLH }\end{array}$ \\
\hline
\end{tabular}

\begin{tabular}{|c|c|c|c|c|c|c|c|c|c|}
\hline $\begin{array}{l}\text { Present } \\
\text { report }\end{array}$ & 2016 & $31 \mathrm{~F}$ & 8 & Lamotrigine & $\begin{array}{l}\text { Hematologic, } \\
\text { liver, renal, } \\
\text { pulmonary } \\
\text { affection }\end{array}$ & $\begin{array}{l}\text { Bloody } \\
\text { diarrhea }\end{array}$ & $\begin{array}{l}\text { Pancolitis, ulcerative } \\
\text { ileitis and } \\
\text { presence of } \\
\text { pseudomembranes } \\
\text { in sigmoid and } \\
\text { rectum }\end{array}$ & $\begin{array}{l}\text { Ulcerated mucosa Systemic } \\
\text { with inflammatory corticosteroids } \\
\text { infiltrates with } \\
\text { polymorphonuclear } \\
\text { leukocytes } \\
\text { compatible with } \\
\text { sub-acute colitis }\end{array}$ & $\begin{array}{c}\text { Symptoms } \\
\text { resolved }\end{array}$ \\
\hline
\end{tabular}

GI, gastrointestinal; M, male; F, female; HLH, hemophagocytic lymphohistiocytosis.

with systemic corticosteroids with prednisone $1 \mathrm{mg} / \mathrm{kg} /$ day with subsequent complete clinical resolution. Patient was discharged after 15 days of hospitalization; within 2 months, systemic corticosteroids were progressively tapered down and anticonvulsant therapy was replaced with levetiracetam $1000 \mathrm{mg}$ q8 hr.

\section{Discussion}

DRESS syndrome is a type IV hypersensitivity reaction. However, the hallmark of DRESS syndrome is the presence of systemic manifestations. ${ }^{10}$ Although diagnostic criteria have not been adopted officially, a Japanese work group established a series of guidelines for the diagnosis of DRESS syndrome in 2007, and alternatively Kardaun and colleagues in association with the Severe Cutaneous Adverse Reactions study group (RegiSCAR) published a scoring system in 2007. ${ }^{11}$ The patient described here met previous criteria for a definitive case for DRESS syndrome.

Gastrointestinal involvement in the setting of anticonvulsant hypersensitivity syndrome is rare, with less than a dozen of cases reported in the literature. ${ }^{8}$ Gastrointestinal involvement in DRESS syndrome has only been reported in three previous cases (Table 2). ${ }^{8,12}$ Most cases of anticonvulsant-induced drug reactions with gastrointestinal involvement reported eosinophils as the predominant inflammatory infiltrate in the biopsies; mucosal erosion and ulceration have been reported as well. Nonetheless, a detailed description of pathological findings in gastrointestinal injury in DRESS syndrome has not been described to date. ${ }^{8}$ In our case, colonoscopy showed pancolitis and ulcerative ileitis with presence of pseudomembranes. Histological features were not consistent with inflammatory bowel disease or infectious coli- tis. In addition, other important causes of pseudomembranous colitis were ruled out, mainly CDI (negative PCR in stool). Pseudomembranous colitis has been reported secondary to other medications and drugs, such as alosetron, cisplatin, cocaine, cyclosporine A, dextroamphetamine and paraquat $;{ }^{9}$ to our knowledge, pseudomembranous colitis associated with lamotrigineinduced DRESS syndrome, has never been reported before. The diagnosis of drug-related gastrointestinal injury was made based on the pattern of clinical presentation and the temporal association between the addition of the offending drug and the onset of symptoms and gastrointestinal involvement.

In the clinical context of hypersensitivity reactions an extensive work up to stablish systemic involvement should be performed. The main lessons learned from the field out of this case are to rise up clinical awareness, stablish the importance of an exhaustive patient inter- 
rogation and physical examination, and exclude other infectious and inflammatory autoimmune process. Antinuclear antibodies and complementary work up for autoimmune process; polymerase chain reaction for Clostridium Difficile and discard of other infective causes of pseudomembranous colitis and generalized rash, in addition to computed tomography, colonoscopy and biopsy are example of valuable tools in this case report and should not be delayed and be considered in the right clinical practice scenario.

Prompt recognition of the adverse drug reaction and discontinuation of offending medication are imperative steps in limiting the progression of DRESS syndrome. The French Society of Dermatology published a report in 2010 outlining a consensus on therapeutic management of DRESS syndrome, recommending the use of systemic corticosteroids and/or IVIG for patients with lifethreatening disease. ${ }^{13}$

\section{Conclusions}

In summary, DRESS syndrome is a relatively rare entity; however, given the frequent use of antiepileptic drugs, it is paramount that clinicians be aware of the possibility of enterocolitis associated with antiepileptic drugs and DRESS syndrome in the appropriate clinical context. Furthermore, DRESS syndrome should be regarded as an etiology of pseudomembranous colitis. Early recognition and the immediate cessation of the offending medications are essential steps to achieve the best outcome.

\section{References}

1. Bocquet H, Bagot M, Roujeau JC. Druginduced pseudolymphoma and drug hypersensitivity syndrome (Drug Rash with Eosinophilia and Systemic Symptoms: DRESS). Semin Cutan Med Surg 1996;15:250-7.

2. Hall DJ, Fromm JS. Drug reaction with eosinophilia and systemic symptoms syndrome in a patient taking phenytoin and levetiracetam: a case report. J Med Case Rep 2013;7:2.

3. Ortonne N, Valeyrie-Allanore L, BastujiGarin S, et al. Histopathology of drug rash with eosinophilia and systemic symptoms syndrome: a morphological and phenotypical study. Br J Dermatol 2015;173:50-8.

4. Mockenhaupt M. Epidemiology of cutaneous adverse drug reactions. Chem Immunol Allergy 2012;97:1-17.

5. Shiohara T, Iijima M, Ikezawa Z, et al. The diagnosis of a DRESS syndrome has been sufficiently established on the basis of typical clinical features and viral reactivations. Br J Dermatol 2007;156:1083-4.

6. Gonçalo M, Coutinho I, Teixeira V, et al. HLA-B*58:01 is a risk factor for allopurinol-induced DRESS and Stevens-Johnson syndrome/toxic epidermal necrolysis in a Portuguese population. Br J Dermatol 2013;169:660-5.

7. Genin E, Chen DP, Hung SI et al. HLA$A^{*} 31: 01$ and different types of carbamazepine-induced severe cutaneous adverse reactions: an international study and meta-analysis. Pharmacogenomics J 2014;14:281-8.

8. Swanson EA, Low L, Naini BV. Severe enterocolitis associated with antiepilepticinduced drug reaction with eosinophilia and systemic symptoms. Hum Pathol 2014;45:1973-7.

9. Farooq PD, Urrunaga NH, Tang DM, von Rosenvinge EC. Pseudomembranous colitis. Dis Mon 2015;61:181-206.

10. Cacoub P, Musette P, Descamps V, et al. The DRESS syndrome: a literature overview. Am J Med 2011;124:588-97.

11. Shiohara T, Iijima M, Ikezawa Z, et al. The diagnosis of DRESS syndrome has been sufficiently established on the basis of typical clinical features and viral reactivations. Response Br J Dermatol 2007;156: 1045-92.

12. Do-Pham G, Charachon A, Duong TA. Drug reaction with eosinophilia and systemic symptoms and severe involvement of digestive tract: description of two cases. $\mathrm{Br}$ J Dermatol 2011;165:207-9.

13. Descamps V, Ben-Saïd B, Sassolas B, et al. Management of drug reaction with eosinophilia and systemic symptoms (DRESS). Ann Dermatol Venereol 2010;137:703-8. 